\title{
HUBUNGAN ANTARA FREKUENSI BABY SPA DENGAN POLA TIDUR PADA BAYI USIA 6-12 BULAN DI KLINIK ALMAWADAH 2 DAY CARE
}

\author{
KABUPATEN BATANG
}

\author{
Hilda Prajayanti ${ }^{1}$, Ida Baroroh ${ }^{2}$, Swasti Artanti ${ }^{3}$ \\ hi3l17a.praja@yahoo.co.id \\ Akademi Kebidanan Harapan Ibu Pekalongan \\ Jl. Sriwijaya No. 7 Kota Pekalongan. \\ Telp 085102998866
}

\begin{abstract}
ABSTRAK
Istirahat dan tidur yang tepat sama pentingnya dengan nutrisi yang baik dan latihan yang adekuat. Aktivitas tidur merupakan salah satu stimulasi bagi tumbuh dan kembang bayi (Perry et al, 2006). Indonesia cukup banyak bayi yang mengalami masalah tidur, yaitu sekitar $44,2 \%$ bayi mengalami gangguan tidur seperti sering terbangun di malam hari. Namun hampir atau bahkan lebih dari $72 \%$ orang tua tidak menganggap gangguan tidur pada bayi sebagai suatu masalah.Meskipun dianggap masalah mereka hanya menganggapnya sebagai masalah kecil. Padahal, masalah tidur dapat menganggu pertumbuhan bayi, menyebabkan fungsi imun rentan, dan mengganggu regulasi system endokrin. Baby spa merupakan perawatan spa tubuh pada bayi yang dapat dilakukan dengan dua cara, yaitu mandi berendam atau berenang dan pijat. Manfaat baby spa ini dapat memberikan rasa tenang, nyaman, dan segar. Hantaman air yang ditimbulkan dari air yang bergolak dapat memberi sensasi dan pijatan yang menghilangkan lelah, melancarkan peredaran darah dan menciptakan relaksasi.Klinik Almawadah 2 Day Care Batang merupakan salah satu klinik yang memberikan pelayanan pijat bayi maupun baby spa. Penelitian ini menggunkan jenis penelitian analitik adalah penelitian yang mencoba menggali bagaimana dan mengapa fenomena kesehatan terjadi. Kemudian melakukan dinamika korelasi antara fenomena atau antara faktor resiko dengan efek. Yang dimaksud efek adalah suatu akibat dari adanya faktor resiko, sedangkan faktor resiko adalah suatu fenomena yang mengakibatkan terjadinya efek (pengaruh) (Notoatmodjo, 2012). Rancangan penelitian yang digunakan adalah cross sectional yang menekankan pada waktu pengukuran atau observasi data variable independen dan dependen hanya satu kali pada satu itu. Dari hasil penelitian mengenai hubungan antara baby spa dengan kualitas tidur bayi usia 6-12 bulan di Almawadah 2 DayCare Denasri Kulon Kabupaten Batang sebagai berikut: Sebagian besar Pendidikan Ibu SMA yang melakukan baby spa bayinya secara rutin, Sebagian besar bayi tidur nyenyak setelah dilakukan baby spa dan Ada hubungan antara baby spa dengan kualitas tidur.
\end{abstract}

Kata Kunci

: Bayi, Baby Spa, Pola Tidur

\section{Pendahuluan}

Istirahat dan tidur yang tepat sama pentingnya dengan nutrisi yang baik dan latihan yang adekuat. Aktivitas tidur merupakan salah satu stimulasi bagi tumbuh dan kembang bayi (Perry et al, 2006). Menurut UU No 36 Tahun 2009 tentang kesehatan pasal 133 menyatakan bahwa pasal (1) setiap bayi dan anak berhak terlindungi dan terhindar dari segala bentuk diskriminasi dan tindak kekerasan yang dapat mengganggu kesehatannya dan pasal (2) Pemerintah, pemerintah daerah, dan masyarakat berkewajiban untuk menjamin terselenggaranya perlindungan bayi dan anak sebagaimana dimaksud pada ayat (1) dan

menyediakan pelayanan kesehatan sesuai dengan kebutuhan.

Indonesia cukup banyak bayi yang mengalami masalah tidur, yaitu sekitar $44,2 \%$ bayi mengalami gangguan tidur seperti sering terbangun di malam hari. Namun hampir atau bahkan lebih dari $72 \%$ orang tua tidak menganggap gangguan tidur pada bayi sebagai suatu masalah.Meskipun dianggap masalah mereka hanya menganggapnya sebagai masalah kecil. Padahal, masalah tidur dapat menganggu pertumbuhan bayi, menyebabkan fungsi imun rentan, dan mengganggu regulasi system endokrin (Rizema,2011;h.69) . 
Tidur merupakan prioritas utama bagi bayi, karena aktivitas tidur merupakan stimulus bagi proses tumbuh kembang otak. Sebab,75\% hormon pertumbuhan dikeluarkan saat tidur. Hormon pertumbuhan inilah yang bertugas merangsang pertumbuhan tulang dan jaringanya.Selain itu hormon pertumbuhan juga memungkinkan tubuh memperbaiki dan memperbarui seluruh sel yang ada di tubuh, mulai dari sel kulit, sel darah, sampai sel saraf otak. Proses pembaruan sel tersebut akan berlangsung lebih cepat bila bayi sering kali terlelap tidur sesuai dengan kebutuhan tidurnya. Tidur juga membantu perkembangan psikis emosi, kognitif, konsolidasi pengalaman dan kecerdasan.Bayi menghabiskan jumlah rata-rata waktu tidur sekitar $60 \%$.Pola siklus tidur-bangun terlihat jelas pada umur 3-5 bulan, dimana proporsi tidur mulai lebih banyak pada malam hari. Secara umum morning naps( tidur di pagi hari) berhenti umur 1 tahun dan afternoon naps ( tidur di sore hari ) berlangsung umur 3 tahun (Rizema, 2011; h.67) .

Waktu untuk tidur bayi kurang lebih 18 jam perhari dan waktu yang tersisa untuk bayi adalah bermain melakukan aktivitas yang membuat bayi nyaman, misalnya bercengkrama dengan ibu dan anggota keluarga. (Ismail, 1994 dalam Widodo, A. 2012; h.3).

Tidur yang tidak adekuat dapat mengakibatkan gangguan keseimbangan fisiologi dan psikologi. Dampak fisiologi meliputi penurunan aktivitas sehari-hari, rasa capai, lemah, koordinasi neuromuskular buruk, proses penyembuhan lambat dan daya tahan tubuh menurun. Sedangkan dampak psikologinya meliputi emosi lebih labil, cemas, tidak konsentrasi, kemampuan kognitif dan menggabungkan pengalamannya lebih rendah. Namun, kelebihan waktu tidur (terutama tidur tenang) menyebabkan terjadi penyimpanan energi berlebihan. Anakpun kurang aktif bermain, sehingga kurang berinteraksi menyebabkan perkembangan emosi dan kognitifnya kurang optimal (Turchin, 2000; Bukit, 2003; Soedjatmiko, 2006; Saputra, 2009).

$$
\text { Menurut Permenkes No. }
$$

1205/Menkes/X/2004, spa merupakan upaya tradisional yang menggunakan pendekatan holistik, melalui perawatan menyeluruh dengan menggunakan metode kombinasi antara hidroterapi (terapi air) dan massage (pijat) yang dilakukan secara terpaduuntuk menyeimbangkan tubuh, pikiran, serta perasaan. Baby spa merupakan perawatan spa tubuh pada bayi yang dapat dilakukan dengan dua cara, yaitu mandi berendam atau berenang dan pijat. Manfaat baby spa ini dapat memberikan rasa tenang, nyaman, dan segar. Hantaman air yang ditimbulkan dari air yang bergolak dapat memberi sensasi dan pijatan yang menghilangkan lelah, melancarkan peredaran darah dan menciptakan relaksasi. Tidur bayi akan semakin lelap sehingga dapat meningkatkan jumlah jam tidur siang dan malam. Dimana dalam tidur bayi ini terjadi peningkatan pengeluaran hormon pertumbuhan.

Berendam dan berenang akan merangsang gerakan motorik bayi. Ketika bermain air, otot - otot bayi akan berkembang dengan sangat baik, persendian tumbuh secara optimal, pertumbuhan badanmeningkat, dan tubuhpun menjadi lentur. Gerakan berenang didalam air semua anggota tubuh bayi akan terlatih, karena seluruh anggota tubuh digerakkan mulai dari kaki, tangan hingga kepala walaupun belum sempurna. Selain itu kemampuan mengontrol otot bayi akan lebih meningkat karena pada saat berenang didalam air efek gravitasi sangat rendah sehingga memungkinkan bayi untuk bergerak lebih banyak dan semua otot pun dapat bekerja dengan optimal. (Yahya, 2011 dalam Qoriesa, 2012; h.5).

Mandi berendam sangat efektif untuk menghilangkan kelelahan dan kejenuhan.Pada bayi dan anak, mandi berendam merupakan pilihan yang tepat untuk membantu menghilangkan kelelahannya. Bayi yang berendam, sebagian besar tubuhnya akan terkena air dalam waktu cukup lama dan dengan suasana menyenangkan, tubuh merekapun akan jauh lebih segar dan lebih bersih. Sebenarnya sejak dalam perut ibu, bayi sudah bisa berenang dalam air ketuban. Meletakkan bayi usia dibawah tiga bulan di dalam air, secara refleks ia akan menggerakgerakkan kaki agar tidak tenggelam. Bisa dikatakan, pada usia dibawah tiga bulan bayi sudah bisa berenang dengan gaya primitive. Adanya gaya gravitasi, bayi merasa ditekan dari bawah air sehingga ia bisa mengambang.

Pijat adalah seni perawatan kesehatan dan pengobatan yang dipraktekkan sejak berabad-abad silam.Bahkan, diperkirakan ilmu ini telah dikenal sejak awal manusia diciptakan 
ke dunia, karena pijat sangat berhubungan erat dengan kehamilan dan proses kelahiran manusia (Roesli, 2010 dalam Indaryani 2012; h.7).

Pemijatan bayi lebih dini, bayi akan memperoleh manfaat lebih besar. Bayi yang di pijat akan terlihat lebih responsif, dapat lebih banyak menyapa dengan kontak mata, lebih banyak tersenyum, lebih banyak bersuara, lebih banyak menanggapi, lebih cepat mengenal lingkungan, dan lebih tanggap. Pijat bayi dapat mempengaruhi hormon melatonin, dengan hormon tersebut hormone tersebut bayi dapat memiliki pola tidur teratur. Efek dari tindakan pijat adalah mengembalikaan hormon stress sehingga tidak mengejutkan bayi dan memberikan rasa nyaman dan tenang sehingga meningkatkan kualitas tidurnya. (Budhiarta, 2011 dalam Indriyani, 2012; h.2).

Tahun pertama kehidupannya, bayi mengalami perkembangan yang pesat pada otaknya.Renang bayi telah diketahui bermanfaat dalam merangsang perkembangan otak secara optimal, menguatkan saraf, dan meningkatkan kualitas tidur, meningkatkan pertumbuhan motorik. Air sebagai mediadalam renang ini, memungkinkan bayi untuk bisa bergerak dengan bebas. Kondisi berenang ini sama denagn bayi ketika masih dalam kandungan, saat bayi masih dikelilingi dengan air ketuban ibu. Sehingga bayi memiliki refleks gerak kaki yang banyak dan sering, gerak ini sangat membantunya ntuk berenang.

Klinik Almawadah 2 Day Care merupakan salah satu klinik yang memberikan pelayanan pijat bayi maupun baby spa. Setelah dilakukan studi pendahuluan pada tanggal 4 Oktober 2016, di dapatkan enam pijat bayi dan lima baby spa yang berkunjung ke Klinik Almawadah 2 Day Care. Dari kunjungan tersebut 5 (lima) orang tua dari bayi ternyata 3 (tiga) orang tua bayi yang melakukan baby spa selama $2 \mathrm{x}$ dalam seminggu, orang tua bayi mengatakan tidur bayinya semakin lelap dan lebih lama karena tidak rewel. Semua pasien yang melakukan baby spa adalah bertujuan untuk mengoptimalkan atau merangsang pertumbuhan bayi dan olahraga. Sedangkan 2 (dua) orang tua bayi mengatakan perkembangan dan pertumbuhan bayinya lebih aktif, untuk pola tidurnya tidak teratur karena bayi sering rewel dan tidur siang 3 jam, tidur malam 10 jam dan 1 orang ibu mengatakan tidur bayinya tidak teratur karena tidur siang 5 jam dan tidur malam 8 jam. Dari lima bayi yang melakukan baby spa, dua bayi mengalami pola tidur teratur. Jumlah kunjungan ke Klinik Almawadah Day Care untuk melakukan baby spa dalam kurun waktu satu bulan lebih dari dua puluh kunjungan.

Penelitian ini mempunyai tujuan diketahuinya pengaruh pola tidur bayi sebelum dan sesudah mendapatkan pijat bayi dengan baby spa pada bayi usia 6-12 bulan diKlinik Almawadah 2 Day Care Kabupaten Batang.

\section{Metode Penelitian}

Metodologi penelitian sebagai cara untuk memperoleh kebenaran ilmu pengetahuan atau pemecahan suatu masalah, pada dasarnya menggunkan metode ilmiah (Notoatmodjo, 2012). Penelitian ini menggunkan jenis penelitian analitik adalah penelitian yang mencoba menggali bagaimana dan mengapa fenomena kesehatan terjadi. Kemudian melakukan dinamika korelasi antara fenomena atau antara faktor resiko dengan efek. Yang dimaksud efek adalah suatu akibat dari adanya faktor resiko, sedangkan faktor resiko adalah suatu fenomena yang mengakibatkan terjadinya efek (pengaruh) (Notoatmodjo, 2012) . Tujuan penelitian ini adalah membuktikan adanya hubungan antara baby spa dengan kualitas tidur bayi. Rancangan penelitian pada hakekatnya merupakan suatu strategi untuk mencapai tujuan penelitian yang telah ditetapkan dan berperan sebagai pedoman atau penuntun pada seluruh proses penelitian (Nursalam, 2008)

Rancangan penelitian yang digunakan adalah cross sectional yang menekankan pada waktu pengukuran atau observasi data variable independen dan dependen hanya satu kali pada satu itu (Nursalam, 2008). Rancangan penelitian ini adalah cross sectional. Rancangan cross sectional, ialah suatu penelitian untuk mempelajari dinamika korelasi antara faktor-faktor risiko dengan efek, dengan cara pendekatan, observasi atau pengumpulan data

sekaligus pada suatu saat (point time apporoach). Artinya, setiap subjek penelitian 
hanya diobservasi sekali saja dan pengukuran dilakukan terhadap status karakter

atau variable subjek pada saat pemeriksaan (Notoatmodjo, 2012).

\section{Hasil dan Pembahasan}

a. Pendidikan Orang Tua

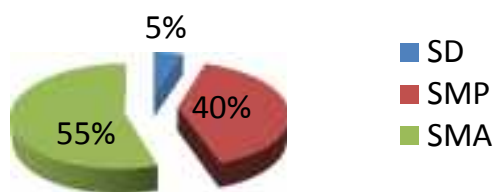

Berdasarkan hasil dari data yang dikumpulkan oleh peneliti seperti yang tercantum dalam gambar 4.1 diatas didapatkan bahwa dari 20 orang tua, jumlah pendidikan terakhir terbanyak adalah SMA sejumlah $11 \mathrm{ibu}$ (55\%) dan 1 ibu (10\%) pendidikan terakhir SD.

Menurut hasil penelitian pendidikan sebagaian besar ibu berpendidikan SMA 11 ibu (55\%), $\quad 1$ ibu (10\%) berpendidikan SD, dan 8 ibu (35\%) berpendidikan SMP. Hal ini sesuai dengan teori yang dikemukan dalam penelitian Indriati (2010) bahawa Pendidikan adalah suatu proses belajar dimana proses pertumbuhan, perkembangan atau perubahan kearah yang lebih dewasa, lebih baik dan lebih matang pada diri individu, kelompok, masyarakat menurut Alimul A (2007). Dengan demikian, semakin tinggi pendidikan ibu, akan mendorong ibu untuk memenuhi kebutuhan tidur bayinya.

b. Pekerjaan Orang Tua

$15 \%$

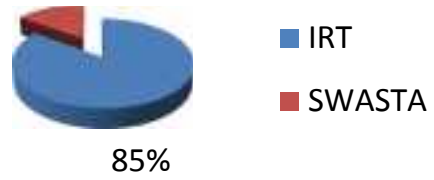

Berdasarkan hasil dari data yang dikumpulkan oleh peneliti seperti yang tercantum dalam gambar 4.2 diatas didapatkan bahwa dari 20 orang tua, jumlah pekerjaan terbanyak adalah ibu rumah tangga sebanyak $17 \mathrm{ibu}$ (85\%) dan 3 ibu (15\%) pekerja swasta

Ditinjau dari segi pekerjaan, ibu yang mempunyai pekerjaan akan mempunyai pendapatan sendiri dan akan tetapi membuat para ibu meluangkan waktunya hanya sebentar untuk bayinya. Sedangkan ibu yang tidak bekerja mempunyai banyak waktu untuk bersama bayinya dan mampu untuk memenuhi kebutuhan tidur bayinya. Dalam penelitian ini banyak ibu yang tidak bekerja dan ibu rumah tangga sejumlah 17 ibu (85\%) sedangkan $3 \mathrm{ibu}(15 \%)$ pekerja swasta. Menurut Indriati (2010) dalam penelitiannya menyatakan bahwa kenaikan tingkat partisipasi wanita dalam angkatan kerja dan adanya emansipasi dalam segala bidang kerja menyebabkan menurunnya kesediaan ibu untuk merawat bayinya.

c. Baby Spa

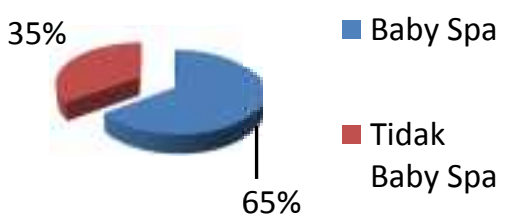

Berdasarkan hasil dari data yang dikumpulkan oleh peneliti seperti yang tercantum dalam gambar 4.3 diatas didapatkan bahwa dari 20 bayi sebanyak 13 (60\%) bayi yang dibaby spa dan 7 (35\%) bayi yang tidak dibaby spa.

Menurut hasil penelitian ini terdapat $65 \%$ bayi dibaby spa terdapat $35 \%$ bayi tidak dibaby spa. Hal ini menunjukkan bahwa sebagian besar orang tua sudah paham dengan manfaat dari baby sapa. Hal ini terbukti dari hasil pengumpulan data kuesioner yang terbanyak menjawab "ya" pada pertanyaan tentang baby spa. 
Hal ini sesuai dengan pendapat Roesili (2010) bahwa baby spa dapat segera dimulai setelah bayi dilahirkan, sesuai keinginan orang tua. Dengan lebih cepat mengawali pemijatan, bayi akan mendapat keuntungan yang lebih besar. Apalagi jika baby spa dapat dilakukan setiap hari dari sejak kelahiran sampai bayi berusia 12 bulan.

d. Pola Tidur Bayi 6-12 Bulan

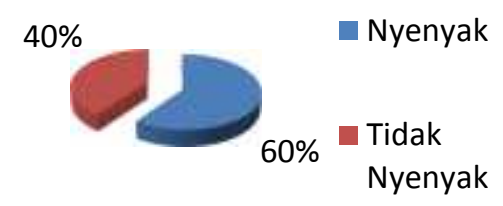

Berdasarkan hasil dari data yang dikumpulkan oleh peneliti seperti yang tercantum dalam gambar 4.4 diatas didapatkan dari 20 bayi sebanyak $12(60 \%)$ bayi tidur nyenyak dan 8 (40\%) bayi tidur tidak nyenyak.

Hal ini sesuai dengan pendapat Roesli (2010) bahwa baby spa dapat meningkatakan kadar serotonin yang akan mengahsilkan melatonin yang berperan dalam tidur dan membuat tidur lebih lama dan lelap pada malam hari. Serotonin juga akan meningkatkan kapasitas sel reseptor yang berfungsi mengikat glukokortikoid (adrenalin suatu hormon stress). Proses ini menyebakan terjadinya penerunan kadar hormon adrenalin (hormon stress) sehingga bayi yang diberi perlakuan baby spa akan tampak lebih tenang dan tidak rewel. Baby spa juga meningkatkan mekanisme penyerapan makanan oleh nervus vagus sehingga nafsu makan bayi meningkat.

e. Hubungan antara pijat bayi dengan pola tidur bayi

Hasil penelitian menggambarkan bahwa 13 bayi yang dipijat sebanyak 10 bayi Pola tidur bayi dikategorikan nyenyak dan 3 bayi tidak nyenyak. Sedangkan 7 bayi yang tidak dibaby spa 2 bayi dikategorikan tidurnya nyenyak dan 5 bayi tidak nyenyak.

Hasil uji fisher exact didapatkan hasil $p=0,045 \leq \alpha=0,05$ maka H0 ditolak kesimpulannya ada hubungan antara pijat bayi dengan pola tidur bayi usia 6-12 bulan di Klinik Almawadah Hasil uji statistic sebagai berikut:

Hubungan baby spa dan pola tidur bayi di Klinik Almawadah 2 Tahun 2016

\begin{tabular}{|c|c|c|c|}
\hline \multirow{3}{*}{$\begin{array}{l}\text { Pola } \\
\text { tidur } \\
\text { bayi }\end{array}$} & \multicolumn{2}{|c|}{ Baby spa bayi } & \multirow[t]{2}{*}{ Jumlah } \\
\hline & $\begin{array}{c}\text { Dibaby } \\
\text { spa }\end{array}$ & $\begin{array}{l}\text { Tidak } \\
\text { dibab } \\
\text { y spa }\end{array}$ & \\
\hline & $\begin{array}{c}\mathrm{f} \\
\% \\
\end{array}$ & $\begin{array}{c}\mathrm{f} \\
\%\end{array}$ & $\begin{array}{c}\mathrm{f} \\
\% \\
\end{array}$ \\
\hline Nyenyak & $\begin{array}{l}10 \\
83.4\end{array}$ & $\begin{array}{l}2 \\
16,5 \\
\end{array}$ & $\begin{array}{l}12 \\
100 \\
\end{array}$ \\
\hline $\begin{array}{l}\text { Tidak } \\
\text { nyenyak }\end{array}$ & $\begin{array}{l}3 \\
37,5 \\
\end{array}$ & $\begin{array}{l}5 \\
62,5 \\
\end{array}$ & $\begin{array}{l}8 \\
100 \\
\end{array}$ \\
\hline Jumlah & $\begin{array}{l}13 \\
65 \\
\end{array}$ & $\begin{array}{l}7 \\
35 \\
\end{array}$ & $\begin{array}{l}20 \\
100 \\
\end{array}$ \\
\hline \multicolumn{4}{|c|}{$\mathrm{p}=0,047 \leq \alpha 0,05$} \\
\hline $\begin{array}{l}\text { diduku } \\
\text { dikemu } \\
\text { menyat } \\
\text { sangat } \\
\text { Pemija } \\
\text { santai } \\
\text { mening } \\
\text { tidurny } \\
\text { tekanar } \\
\text { menuru } \\
\text { adrenal } \\
\text { mening } \\
\text { bayi. B } \\
\text { tubuh } \\
\text { endrorp } \\
\text { dapat } \\
\text { ketidak } \\
\text { si } \\
\text { konsen } \\
\text { yang d } \\
\text { lelap } \\
\text { bangun } \\
\text { penuh. } \\
\text { spa da } \\
\text { otak. } \\
\text { dengan } \\
\text { gelomb }\end{array}$ & $\begin{array}{l}\text { Iubungan } \\
\text { lg oleh } \\
\text { kan oleh } \\
\text { akan bah } \\
\text { baik bag } \\
\text { an memb } \\
\text { dan tenan } \\
\text { katkan } \\
\text { a. Mengu } \\
\text {, pijatan } \\
\text { nkan pro } \\
\text { in yang } \\
\text { katkan di } \\
\text { aby spa le } \\
\text { nelepaska } \\
\text { hin, ked } \\
\text { membar } \\
\text { nyamanan } \\
\text { kecil. } \\
\text { rasi bayi, } \\
\text { ipijat aka } \\
\text { sehingga } \\
\text { konsentra } \\
\text { Hal ini } \\
\text { pat meng } \\
\text { Pengubah } \\
\text { cara } \\
\text { ang }\end{array}$ & $\begin{array}{l}\text { teori } \\
\text { Naswa } \\
\text { wa pac } \\
\text { i keseh } \\
\text { uat anc } \\
\text { g sehin } \\
\text { ef } \\
\text { angi st } \\
\text { meneng } \\
\text { duksi } \\
\text { elanjutn } \\
\text { ya taha } \\
\text { mbut m } \\
\text { oksitc } \\
\text { a horm } \\
\text { tu m } \\
\text { yang d } \\
\text { Menir } \\
\text { umumr } \\
n \text { tertid } \\
\text { pada } \\
\text { sinya ak } \\
\text { lisebabk } \\
\text { bah ge } \\
\text { an ini } \\
\text { men } \\
\text { alpha }\end{array}$ & $\begin{array}{l}\text { yrsebut } \\
\text { yang } \\
(2015) \\
\text { anak } \\
\text { tannya. } \\
\text { lebih } \\
\text { ga bisa } \\
\text { ktivitas } \\
\text { ess dan } \\
\text { an dan } \\
\text { ormone } \\
\text { a akan } \\
\text { tubuh } \\
\text { mbantu } \\
\text { in dan } \\
\text { ne itu } \\
\text { ngatasi } \\
\text { rasakan } \\
\text { gkatkan } \\
\text { ya bayi } \\
\text { r lebih } \\
\text { waktu } \\
\text { an lebih } \\
n \text { baby } \\
\text { ombang } \\
\text { terjadi } \\
\text { irunkan } \\
\text { dan }\end{array}$ \\
\hline
\end{tabular}


meningkatkan gelombang beta serta tetha, yang dapat dibuktikan dengan penggunaan EEG (electro encephalogram).

Selain dari baby spa bayi ada faktor lain yang dapat mempengaruhi pola tidur bayi, Menurut Perry and Potter (2006) mengatakan bahwa factor lingkungan, latihan fisik, nutrisi dan penyakit juga sangat mempengaruhi pola tidur bayi.

\section{Simpulan}

Dari hasil penelitian mengenai hubungan antara baby spa dengan kualitas tidur bayi usia 6-12 bulan di Almawadah 2 DayCare Denasri Kulon Kabupaten Batang sebagai berikut:

a. Sebagian besar Pendidikan Ibu SMA yang melakukan baby spa bayinya secara rutin

b. Sebagian besar bayi tidur nyenyak setelah dilakukan baby spa

c. Ada hubungan antara baby spa dengan kualitas tidur

\section{Daftar Pustaka}

[1] Galenia. 2014. Home Baby SPA.Jakarta : Penebar Swadaya

[2] Indriyani, H. 2012. PengaruhPijat Bayi terhadap Kualitas Tidur Bayi umur 0-3 bulan di Desa Keji Kecamatan Ungaran Barat Kabupaten Semarang.[Diakses tanggal 23 Febuari 2015]. Di dapat dari : Skripsi, http://www.perpusnwu.web.id/k aryailmiah

[3] Kurniawan, A.2013. Hubungan Frekuensi Kunjungan Solus Per Aqua (SPA) Bayi kaitannya dengan Kenaikan Berat Badan Bayi Umur 0-6 bulan di Puskesmas Gantiwarno Klaten .[Diakses tanggal 4 Juni 2015]. Di dapat dari :Jurnal Terpadu Ilmu Kesehatan, Volume 2, Nomor 2,pdf

[4] Qoriesa, S. 2014. Hubungan Frekuensi Baby SPA dengan perkembangan bayi padausia 46 bulan di Klinik Baby SPA Ananda Kecamatan Ambarawa Kabupaten Semarang.[Diakses 29 Desember 2014]. Di dapat dari

Skripsi,http://www.perpusnwu. web.id/karyailmiah

[5] Rizema, S. 2011. Tips Sehat dengan Pola Tidur Tepat dan Cerdas.Yogyakarta : Buku Biru

[6] Roesli, U. 2010. Pedoman Pijat Bayi. PT TrubusAgriwidya : Jakarta

[7] Septiari, B. 2012.Mencetak Balita Cerdas dan Pola Asuh Orang Tua.Yogyakarta : Nuha Medika

[8] Widodo, Agus. 2012. Efetivitas Baby SPA Terhadap Lamanya Tidur Bayi Usia3-4 Bulan.[Diakses tanggal 28 November 2014]. Di dapat dari: https://publikasiilmiah.ums.ac.id /bitstream/handle/123456789/33 16/12.\%20AGUS\%20WIDODO .pdf 